\begin{tabular}{|l|l}
\hline & JTMT \\
Jurnal Tadris Matematika \\
Vol 1 No 2 2020 \\
ISSN (print) : $2745-956 \mathrm{X}$ \\
ISSN (online) : $2745-9551$ \\
Homepage $: \underline{\text { http://journal.iaimsinjai.ac.id/index.php/Jtm }}$ \\
\hline
\end{tabular}

\title{
PENGARUH MODEL TEAM ASSISTED INDIVIDUALIZATION (TAI) TERHADAP KEMAMPUAN BERPIKIR KRITIS MATEMATIS SISWA BERBASIS MEDIA WHATSAPP
}

\author{
Nurhikmah ${ }^{1}$, Ernawati $^{2}$ \\ ${ }^{1}$ Universitas Muslim Maros, Maros \\ ${ }^{2}$ Universitas Muslim Maros, Maros \\ E-mail:nurhikmahalausy@gmail.com,Tlp/HP:082349885311
}

\begin{abstract}
Abstrak
Penelitian ini merupakan penelitian Pre-experimental yang bertujuan untuk mengetahui pengaruh model pembelajaran kooperatif tipe Team Assisted Individualization (TAI) terhadap kemampuan berpikir kritis matematis siswa berbasis media whatsapp kelas VIII SMP Negeri 11 Maros. Jenis penelitian ini adalah penelitian kuantitatif dengan one group pretest-posttest design. Populasi dalam penelitian ini adalah siswa kelas VIII SMP Negeri 11 Maros dengan sampel yang dipilih menggunakan metode purposive sampling atau dengan pertimbangan kriteria tertentu sebanyak 14 siswa dalam satu kelas eksperimen yaitu kelas VIII A. Pengumpulan data menggunakan tes kemampuan berpikir kritis matematis dan lembar observasi keterlaksanaan pembelajaran yang telah divalidasi oleh ahli. Data penelitian ini dianalisis secara deskriptif dan inferensial dengan uji normalitas sebagai uji prasyarat analisis dan uji paired sample t-test sebagai uji hipotesis. Hasil analisis data menunjukkan bahwa rata-rata hasil pre-test 35,29 sedangkan rata-rata post-test 60,7. Berdasarkan uji-t diperoleh 0,001 $<\alpha=0,025$ yang berarti terdapat peningkatan yang signifikan. Hasil penelitian ini menunjukkan bahwa terdapat pengaruh signifikan pada siswa yang diajar menggunakan model pembelajaran kooperatif tipe Team Assisted Individualization (TAI) terhadap kemampuan berpikir kritis matematis siswa berbasis media whatsapp kelas VIII SMP Negeri 11 Maros.
\end{abstract}

Kata Kunci: Model pembelajaran kooperatif tipe Team Assisted Individualization (TAI), Kemampuan Berpikir Kritis Matematis

\begin{abstract}
This research is a Pre-experimental research that aims to determine the effect of the cooperative learning model type team assisted individualization (TAI) the mathematical critical thinking ability students whatsapp media of class VIII of SMP Negeri 11 Maros. This type of research is quantitative research with one group pretest-posttest design. The population in this study were students of class VIII SMP Negeri 11 Maros with selected samples using the purposive sampling method or with consideration of certain criteria as many as 14 students in one experimental class, namely class VIII A. Data collection using tests of mathematical critical thinking skills and observation sheet on the learning process that have been validated by experts. The data of this study were analyzed descriptively and inferentially with the normality test as a prerequisite test for analysis and paired sample t-test as a hypothesis test. The results of data analysis showed that the average pre-test results were 35,29 while the average post-test was 60,7. Based on the t-test obtained 0,001 $<\alpha=0.025$ which
\end{abstract}


means there is a significant increase. The results of this study indicate that there is a significant influence on students who are taught using the Team Assisted Individualization (TAI) cooperative learning model on the mathematical critical thinking ability students whatsapp media of Class VIII SMP Negeri 11 Maros.

Keywords: Team Assisted Individualization (TAI) type of cooperative learning model, Critical Thinking Ability Mathematics.

\section{Pendahuluan}

Perkembangan kreatifitas dan inovasi yang beragam dalam dunia pendidikan akan senantiasa berubah seiring dengan perkembangan zaman. Perubahan tersebut terjadi disebabkan oleh beberapa faktor penting dalam keberlangsungan pendidikan, salah satunya adalah perubahan pada pola pikir yang dimiliki oleh seorang guru maupun siswa, perubahan itu dimulai dari pola pikir yang masih awam menjadi lebih modern. Sehingga hal tersebut akan mempengaruhi keberhasilan maupun kemajuan suatu pendidikan. Dengan perkembangan pola pikir yang lebih modern ini diharapkan mampu menciptakan seorang guru yang lebih berkualitas. Sebab, kualitas yang dimiliki seorang guru akan mampu menciptakan generasi penerus bangsa yang berkualitas pula serta mampu membentuk pribadi yang lebih kritis, kreatif, dan inovatif dalam menyelesaian suatu permasalahan. Manusia merupakan individu yang senantiasa mencari hal-hal baru untuk dijadikannya sebagai alternatif dalam menyelesaikan permasalahan-permasalahan kehidupan yang senantiasa bermunculan. Seperti halnya pula pada pendidikan, manusia akan senantiasa berpikir keras untuk mencari hal-hal atau alternatif baru yang lebih baik dan dapat digunakan untuk menciptakan pendidikan yang lebih maju.

Dengan terjadinya perkembangan zaman, yang kemudian menciptakan pola pikir yang lebih modern, diharapkan adanya kemajuan yang terjadi pada pendidikan, sehingga dapat tercipta suatu proses pembelajaran yang lebih kreatif dan proses pembelajaran tersebut dapat membentuk kemampuan berpikir kritis siswa. Hal ini diperlukan dalam dunia pendidikan karena masih banyak informasi saat ini yang membutuhkan adanya proses analisa, evaluasi, dan kecermatan yang kritis untuk menemukan solusi serta mengetahui mana informasi yang ternyata salah dan informasi yang benar.

Salah satu mata pelajaran dalam pendidikan yang sangat penting dan membutuhkan kemampuan berpikir kritis adalah mata pelajaran matematika. Hal tersebut disebabkan karena dalam belajar matematika bukanlah semata menghitung dan menghafal rumus, melainkan juga membutuhkan pemahaman terhadap konsep dari rumus tersebut. Mata pelajaran matematika merupakan mata pelajaran yang kurang disenangi, karena mereka merasa kesulitan dalam memahami matematika yang disajikan dalam bentuk pemecahan masalah yang diangkat dari kehidupan seharihari serta memahami simbol-simbol dalam matematika (Ernawati, 2017). Pentingnya mempelajari matematika bukan hanya sekedar memperoleh prestasi yang tinggi dalam bidang matematika, tetapi lebih dari itu matematika merupakan jembatan bagi siswa melatih proses berpikir sistematis, logis, dan kritis dalam menyelesaikan masalah(Fitriani, 2020).

Dengan adanya pemahaman konsep diharapkan siswa mampu lebih kritis dan kreatif dalam hal mengembangkan rumus matematika untuk soal atau permasalahan yang lain. Pembelajaran matematika masih terlihat sebagai suatu kegiatan yang monoton dan prosedural, yaitu guru menerangkan materi, memberi contoh, menugaskan peserta didik untuk mengerjakan latihan soal, mengecek jawaban peserta didik secara sepintas, selanjutnya membahas pemecahan soal yang kemudian dicontohi oleh peserta didik. aspek esensial dari pembelajaran, yaitu proses berpikir peserta didik, seolah-olah diabaikan.(Ernawati, 2015). Seperti yang telah diketahui pula bahwa dalam matematika objek yang dipelajari merupakan objek yang bersifat abstrak, seperti operasi, konsep, maupun prinsipnya. Sehingga, menumbuhkan keterampilan atau kemampuan berpikir kritis siswa sangat diperlukan dalam mata pelajaran matematika, agar penguasaan suatu konsep tidak hanya berupa hafalan dari sejumlah konsep yang telah dipelajarinya, tetapi mereka juga mampu menerapkan 
konsep pada aspek yang lain (Riyanti, A et al., 2016) dan objek yang dipelajari dalam matematika dapat dipahami secara rasional meski objeknya bersifat abstrak. Selain itu, dari hasil observasi dan wawancara yang telah dilakukan kepada salah seorang guru matematika dan siswa kelas VIII SMP Negeri 11 Maros, mengakui bahwa ketika siswa diberikan soal, namun berbeda dengan yang telah dicontohkan oleh gurunya, siswa tersebut mengalami kesulitan dalam menganalisa, menyelesaikan, serta menyimpulkan hasil jawaban dari soal tersebut. Maka, berdasarkan pada kenyataan tersebut dapat diketahui bahwa kemampuan berpikir kritis matematis siswa masih terbilang cukup rendah. Oleh karena itu, perlu adanya upaya untuk mencari alternatif yang bisa digunakan dalam meningkatkan kemampuan berpikir kritis matematis siswa. Salah satu alternatif yang dapat digunakan adalah dengan menggunakan model pembelajaran yang kreatif dan inovatif dalam proses pembelajaran, misalnya dengan menggunakan model pembelajaran kooperatif.

Pembelajaran kooperatif menuntut siswa untuk berdiskusi dalam kelompok secara aktif dan positif serta tetap menghargai ide-ide yang dikemukakan oleh teman kelompoknya. Diharapkan pula dalam pembelajaran ini akan tercipta interaksi yang lebih luas, seperti guru dengan siswa, siswa dengan siswa, dan siswa dengan guru sehingga dapat menumbuhkan kemampuan berpikir kritis matematis siswa (Martiana, 2015). Model pembelajaran kooperatif memiliki banyak tipe, salah satunya adalah model pembelajaran kooperatif tipe Team Assisted Individualization (TAI).

Menurut Slavin model pembelajaran kooperatif tipe Team Assisted Individualization (TAI) merupakan model yang mengkombinasikan keunggulan pembelajaran kooperatif dan pembelajaran individual. Tipe ini dirancang untuk mengatasi kesulitan siswa secara individual. Oleh karena itu, kegiatan pembelajarannya lebih banyak digunakan untuk pemecahan masalah. Ciri khas pada model pembelajaran ini adalah setiap siswa secara individual belajar materi pembelajaran dan mengerjakan soal yang telah diberikan oleh guru. Selanjutnya, hasil yang telah dikerjakan siswa secara individu tersebut dibawa ke kelompok-kelompok yang telah dibentuk oleh guru, untuk kemudian didiskusikan dan saling dibahas bersama. Lalu, setiap anggota kelompok bertanggung jawab atas keseluruhan jawaban sebagai tanggung jawab bersama ((Sumantri, 2016)). Model pembelajaran Team Assisted Individualization (TAI) diharapkan mampu meningkatkan kemampuan berpikir kritis matematis siswa, sebab model pembelajaran ini memiliki keunggulan, dalam hal melatih siswa mengidentifikasi suatu permasalahan serta membuat langkah penyelesaian masalah, kemudian pada saat diskusi kelompok siswa akan saling bertukar pendapat dan melakukan pengecekan terhadap jawaban yang dianggap paling benar. Maka disaat itulah siswa akan dilatih untuk berpikir secara kritis.

Namun, suatu hal yang tidak diharapkan dan telah menjadi ketetapan Allah swt. tengah terjadi dan saat ini menjadi permasalahan hampir di seluruh dunia, ialah terjadimya pandemi Corona Virus Disease 2019 (Covid-19). Covid-19 merupakan penyakit yang disebabkan oleh virus corona yang menyerang sistem pernapasan manusia. Akibat adanya pandemi Covid-19 ini setiap aktivitas keramaian dilarang diadakan sebagai upaya pencegahan penyebaran penyakit Covid-19. Upaya ini kemudian berimbas pula pada proses pendidikan yang terpaksa diliburkan, dan proses pembelajaran dilaksanakan di rumah siswa masing-masing. Dengan pembelajaran yang dilakukan di rumah membuat para guru maupun siswa harus memanfaatkan berbagai teknologi yang ada saat ini demi menunjang keberlangsungan proses pembelajaran. Salah satu, teknologi yang bisa digunakan dalam proses pembelajaran secara daring adalah dengan menggunakan media whatsapp. Media whatsapp menjadi salah satu pilihan yang dapat digunakan dalam proses pembelajaran secara daring karena whatsapp memiliki beberapa kelebihan secara umum dibanding dengan media-media online lainnya. Diantaranya, kerena whatsapp merupakan media yang terbilang lebih mudah dijangkau oleh semua kalangan termasuk siswa yang tinggal di daerah pedalaman yang koneksi jaringan internetnya kurang memadai. Selain itu, whatsapp juga merupakan media yang lebih hemat dipakai sebab tidak memerlukan kuota internet yang mahal dibanding dengan media-media lain.

Maka berdasarkan penjelasan mengenai model pembelajaran kooperatif tipe Team Assisted Individualization (TAI) dan media whatsapp, peneliti akan mencoba melakukan penelitian dengan mengangkat judul "Pengaruh Model Pembelajaran Kooperatif Tipe Team Assisted Individualization 


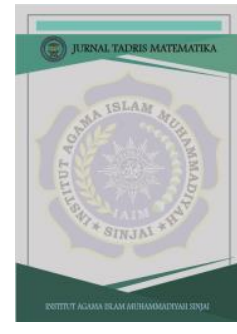

JTMT

Jurnal Tadris Matematika

Vol 1 No 22020

ISSN (print) : 2745-956X

ISSN (online) : 2745-9551

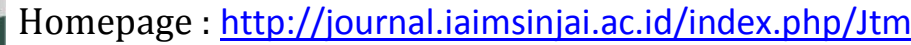

(TAI) Terhadap Kemampuan Berpikir Kritis Matematis Siswa Berbasis Media Whatsapp Kelas VIII SMP Negeri 11 Maros.

\section{Metode}

Jenis penelitian yang digunakan pada penelitian ini adalah Pre-experimental, dengan desain penelitian yang digunakan adalah One Group Pretest Posttest Design. Penelitian ini dilaksanakan pada bulan Mei semester genap tahun ajaran 2019/2020, di SMP Negeri 11 Maros, yang beralamat di Kelurahan Baju Bodoa, Kecamatan Maros Baru, Kabupaten Maros.

Populasi merupakan keseluruhan dari objek, orang, peristiwa, atau sejenisnya, yang menjadi perhatian dan kajian dalam penelitian. Populasi yang digunakan dalam penelitian ini adalah seluruh siswa kelas VIII SMP Negeri 11 Maros. Menurut (Setyosari, 2015)), sampel adalah sekelompok objek, orang, peristiwa, dan sebagainya yang merupakan representasi dari keseluruhan. Sehingga, berdasarkan pengertian sampel tersebut sampel yang digunakan dalam penelitian ini adalah kelas VIII A. Tehink pengambilan sampel yang digunakan dalam penelitian ini adalah purposive sampling. Sebab dalam pemilihan sampel peneliti menggunakan kriteria tertentu, yakni sampel yang terpilih memiliki rata-rata siswa yang aktif.

Variabel bebas pada penelitian ini adalah Model Pembelajaran Kooperatif Tipe Team Assisted Individualization (TAI). Sedangkan Variabel terikat dalam penelitian ini adalah kemampuan berpikir kritis matematis siswa. Prosedur dalam penelitian ini terdapat tiga tahap, yaitu tahap persiapan, tahap pelaksanaan, dan tahap analisis/pengolahan data dan pembuatan kesimpulan. Dalam penelitian ini menggunakan dua tehnik pengambilan data yaitu observasi dan tes untuk mengukur kemampuan berpikir kritis matematis siswa.

Tehnik analisis data dalam penelitian ini menggnakan uji deskriptif dan uji inferensial. Uji deskriptif dilakukan untuk mendapatkan nilai mean, median, modus, range, variansi, dan standar deviasi. Sedangkan uji inferensial digunakan untuk mencari kesimpulan dengan paired sample t-test sebagai uji hipotesisnya.

\section{Hasil dan Pembahasan}

\subsection{Deskripsi Kemampuan Berpikir Kritis Matematis Siswa Kelas VIII A}

Tabel 1. Analisis Deskrtiptif Hasil Tes Kemampuan Berpikir Kritis Matematis Siswa Kelas VIII A

\begin{tabular}{ccc}
\hline & Pre-Test & Post-Test \\
\hline Jumlah Sampel & 14 & 14 \\
Nilai Terendah & 11 & 14 \\
Nilai Tertinggi & 86 & 100 \\
Mean & 35,29 & 60,07 \\
Median & 29,00 & 60,50 \\
Range & 75 & 86 \\
Variansi & 530.681 & 649,610 \\
Standar Deviasi & 23.037 & 25,487 \\
\hline
\end{tabular}

(Sumber: Analisis data dengan SPSS versi 24, 2020)

Berdasarkan Tabel 1. diatas dapat dilihat bahwa setelah siswa kelas VIII A diberikan perlakuan berupa penerapan proses pembelajaran kooperatif tipe Team Assisted Individualization (TAI), nilai hasil tes kemampuan berpikir kritis matematis siswa mengalami peningkatan. Hal tersebut dapat dilihat dari perubahan nilai siswa yang mendapatkan nilai terendah mengalami peningkatan setelah diberikan perlakuan dari 11 hasil Pre-test menjadi 14 hasil Post-test, nilai siswa yang mendapat nilai tertinggi juga meningkat dari 86 menjadi 100, mean (rata-rata) nilai siswa meningkat dari 35,29 menjadi 60,07, dan median nilai siswa meningkat dari 29,00 menjadi 60,50. 


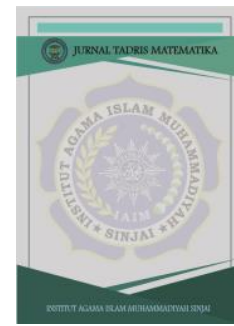

JTMT

Jurnal Tadris Matematika

Vol 1 No 22020

ISSN (print) : 2745-956X

ISSN (online) : 2745-9551

Homepage : http://journal.iaimsinjai.ac.id/index.php/Jtm

Adapun kategorisasi hasil tes kemampuan berpikir kritis matematis siswa kelas VIII A SMP Negeri 11 Maros berdasarkan hasil Pre-test dan Post-test nya, dapat dilihat pada tabel berikut:

Tabel 2. Kategori Hasil Tes Kemampuan Berpikir Kritis Matematis Siswa Berdasarkan

Hasil Pre-Test dan Post-Test

\begin{tabular}{|c|c|c|c|c|c|}
\hline \multirow[b]{3}{*}{ Nilai } & \multirow[b]{3}{*}{ Kategori } & \multicolumn{4}{|c|}{ Kelas Eksperimen } \\
\hline & & \multicolumn{2}{|c|}{ Pre-Test } & \multicolumn{2}{|c|}{ Post-Test } \\
\hline & & 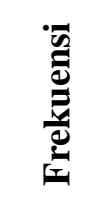 & 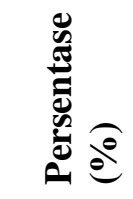 & 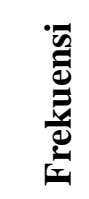 & 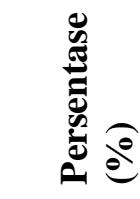 \\
\hline $80-100$ & Sangat Baik & 1 & 7,14 & 3 & 21,43 \\
\hline $66-79,9$ & Baik & 1 & 7,14 & 3 & 21,43 \\
\hline $56-65,9$ & Cukup & 1 & 7,14 & 2 & 14,28 \\
\hline $40-55,9$ & Kurang & 1 & 7,14 & 2 & 14,28 \\
\hline $0-39,9$ & Sangat Kurang & 10 & 71,44 & 4 & 28,58 \\
\hline \multicolumn{2}{|c|}{ Jumlah } & 14 & 100,00 & 14 & 100,00 \\
\hline
\end{tabular}

(Sumber: Analisis kategori kemampuan berpikir kritis)

Berdasarkan tabel 2.kategori hasil tes kemampuan berpikir kritis matematis siswa ditinjau dari hasil Pre-test dan Post-test diatas, terlihat bahwa persentase kemampuan berpikir kritis matematis siswa setelah diterapkan proses pembelajaran dengan model kooperatif tipe Team Assisted Individualization (TAI), mengalami perubahan yang baik. Seperti pada kategori sangat baik persentsenya meningkat dari $7,14 \%$ hasil Pre-test menjadi 21,43\% hasil Post-test dan pada kategori sangat kurang persentasenya menurun dari $71,44 \%$ Pre-test menjadi $28,58 \%$ Post-test.

Berikut adalah deskripsi data hasil tes kemampuan berpikir kritis matematis siswa berdasarkan indikator yang diukur:

Tabel 3. Deskripsi Data Kemampuan Berpikir Kritis MatematisSiswa Berdasarkan Hasil Pre-testdan Post-test

\begin{tabular}{|c|c|c|c|c|c|c|c|c|c|}
\hline \multirow{2}{*}{ No } & \multirow{2}{*}{ Indikator } & \multirow{2}{*}{$\mathbf{N}$} & \multirow{2}{*}{ 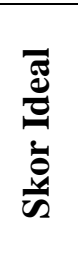 } & \multicolumn{2}{|c|}{$\begin{array}{c}\text { Jumlah } \\
\text { Nilai } \\
\text { Siswa } \\
\end{array}$} & \multicolumn{2}{|c|}{ Rata-Rata } & \multicolumn{2}{|c|}{ Nilai } \\
\hline & & & & 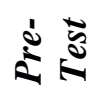 & 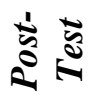 & ऐે & $\underbrace{\dot{\omega}}_{\bar{\sigma}}$ & ปे & 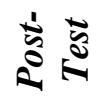 \\
\hline 1 & $\begin{array}{l}\text { Kemampuan mengenal } \\
\text { masalah }\end{array}$ & 14 & 4 & 16 & 33 & 1,5 & 2,36 & 37,5 & 59 \\
\hline 2 & $\begin{array}{l}\text { Kemampuan mengenali } \\
\text { adanya hubungan yang } \\
\text { logis antar masalah }\end{array}$ & 14 & 4 & 12 & 28 & 0,86 & 2 & 21,5 & 50 \\
\hline 3 & $\begin{array}{l}\text { Kemampuan menemukan } \\
\text { cara untuk menyelesaikan } \\
\text { masalah }\end{array}$ & 14 & 16 & 66 & 131 & 4,71 & 9,36 & 29,44 & 58,5 \\
\hline 4 & $\begin{array}{l}\text { Kemampuan } \\
\text { menganalisis data }\end{array}$ & 14 & 4 & 44 & 44 & 3,14 & 3,14 & 78,5 & 78,5 \\
\hline \multicolumn{6}{|c|}{ Rata-Rata } & 2,55 & 4,22 & 37,90 & 61,5 \\
\hline
\end{tabular}

(Sumber: Analisis Indikator Kemampuan Berpikir Kritis Matematis) 


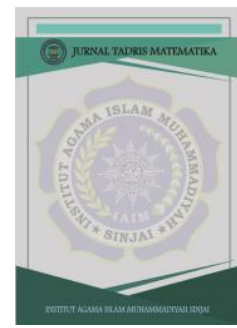

JTMT

Jurnal Tadris Matematika

Vol 1 No 22020

ISSN (print) : 2745-956X

ISSN (online) : 2745-9551

Homepage : http://journal.iaimsinjai.ac.id/index.php/Jtm

Pada tabel 3. deskripsi data kemampuan berpikir kritis matematis siswa berdasarkan hasil Pretest dan Post-test menunjukkan bahwa: pertama rata-rata kemampuan berpikir kritis matematis siswa pada indikator kemampuan mengenal masalah ditinjau dari hasil Pre-test hanya mencapai 1,5 dari skor ideal 4 sedangkan pada hasil Post-test menunjukkan bahwa kemampuan siswa dalam mengenal masalah mengalami peningkatan, hal ini bisa dilihat dari nilai rata-ratanya yang mencapai 2,36 dari skor ideal 4. Sehingga, secara umum setelah siswa diberikan perlakuan berupa proses pembelajaran model kooperatif tipe Team Assisted Individualization (TAI), jumlah siswa yang dapat menuliskan apa yang diketahui dan apa yang ditanyakan pada soal tes kemapuan berpikir kritis matematis siswa telah meningkat dibanding sebelum diberikan perlakuan.

Kedua, rata-rata kemampuan berpikir kritis matematis siswa pada indikator kemampuan mengenali adanya hubungan yang logis antar masalah dilihat dari hasil hasil Pre-test hanya mencapai 0,86 dari skor ideal 4, sedangkan pada hasil Post-test menunjukkan bahwa kemampuan siswa dalam hal mengenali adanya hubungan yang logis antar masalah mengalami peningkatan, hal ini bisa dilihat dari nilai rata-ratanya mencapai 2 dari skor ideal 4. Sehingga, secara umum setelah siswa diberikan perlakuan, jumlah siswa yang dapat menghubungkan informasi yang terdapat pada soal dengan suatu konsep atau rumus yang tepat untuk dapat menyelesaikan masalah pada soal, mengalami peningkatan.

Ketiga, rata-rata kemampuan berpikir kritis matematis siswa pada indikator kemampuan menemukan cara untuk menyelesaikan masalah dilihat dari hasil Pre-test hanya mencapai 4,71 dari skor ideal 16, sedangkan pada hasil Post-test menunjukkan bahwa kemampuan siswa dalam hal menemukan cara untuk menyelesaikan masalah mengalami peningkatan, hal ini bisa dilihat dari nilai rata-ratanya yang mencapai 9,36 dari skor ideal 16. Sehingga, secara umum setelah siswa diberikan perlakuan, jumlah siswa yang sudah mampu menuliskan langkah-langkah perhitungan secara sistematis untuk menyelesaikan suatu masalah pada soal, mengalami peningkatan.

Keempat, rata-rata kemampuan berpikir kritis matematis siswa pada indikator kemampuan menganalisis data ditinjau dari hasil Pre-test dan Post-test tidak mengalami perubahan, hal ini terlihat dari nilai rata-rata Pre-test dan Post-test sama-sama mencapai 3,14 dari skor ideal 4. Sehingga, setelah siswa diberikan perlakuan, terlihat bahwa tidak ada peningkatan pada jumlah siswa dalam hal kemampuan menilai mana pernyataan yang benar dan salah. Namun, secara umum jika dilihat dari nilai rata-rata siswa pada indikator kemampuan menganalisis data, menunjukkan bahwa sebagian besar siswa telah mampu menilai suatu pernyataan yang benar dan salah.

Dari keempat indikator pada tabel 4.3 deskripsi data kemampuan berpikir kritis matematis siswa berdasarkan hasil pre-test dan post-test, terlihat bahwa nilai tertinggi yang diperoleh oleh siswa terdapat pada indikator kemampuan menganalisis data, yaitu 78,5 untuk kedua hasil pre-test dan posttest. Dan nilai terendah yang diperoleh siswa terdapat pada indikator kemampuan mengenali adanya hubungan yang logis antar masalah, yaitu 21,5 untuk hasil pre-test dan 50 untuk hasil post-test. Sehingga, hal ini menunjukkan bahwa siswa lebih mampu dalam hal menilai suatu pernyatan yang benar dan salah, namun kurang dalam hal menghubungkan informasi yang terdapat pada soal dengan suatu konsep atau rumus yang tepat untuk dapat menyelesaikan masalah. Berikut disajikan diagram batang perbedaan nilai setiap indikator kemampuan berpikir kritis matematis siswa di tinjau dari hasil Pre-test danPost-test siswa.

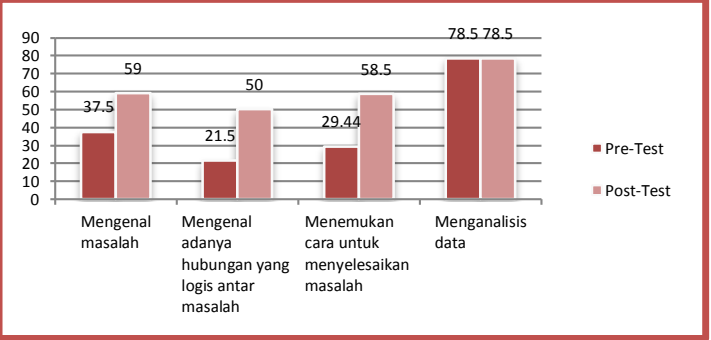

Gambar 1. Diagram Batang Nilai Indikator Kemampuan Berpikir Kritis Matematis Siswa di Tinjau dari Hasil Pre-Test danPost-Test 


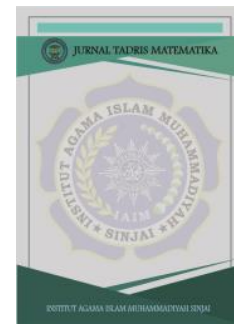

JTMT

Jurnal Tadris Matematika

Vol 1 No 22020

ISSN (print) : 2745-956X

ISSN (online) : 2745-9551

Homepage : http://journal.iaimsinjai.ac.id/index.php/Jtm

Berdasarkan gambar 1.diagram batang nilai indikator kemampuan berpikir kritis matematis siswa di tinjau dari hasil Pre-test dan Post-test di atas, terlihat bahwa indikator menganalisis data memiliki nilai tertinggi untuk kedua hasil Pre-test dan Post-test siswa. Sedangkan indikator menemukan adanya hubungan yang logis antar masalah memiliki nilai yang terendah yaitu 21,5 hasil Pre-test dan 50 hasil Post-test siswa.

\subsection{Analisis Data Hasil Uji Inferensial Kemampuan Berpikir Kritis Matematis Siswa Kelas VIII A}

1. Uji Normalitas

Adapun hasil pengujian normalitas data kemampuan berpikir kritis matematis siswa berdasarkan hasil Pre-test dan Post-test dapat dilihat pada tabel berikut:

Tabel 5 Hasil Uji Normalitas Pre-Test dan Post-Test

\begin{tabular}{lrrrrrr}
\hline & \multicolumn{3}{l}{$\begin{array}{l}\text { Kolmogorov- } \\
\text { Smirnov }^{\mathrm{a}}\end{array}$} & \multicolumn{4}{c}{ Shapiro-Wilk } \\
\cline { 2 - 7 } & Statistic & Df & Sig. & Statistic & df & Sig. \\
\hline PreTest & .250 & 14 & .017 & .879 & 14 & .055 \\
\hline PostTest & .120 & 14 & $.200^{*}$ & .969 & 14 & .866 \\
\hline
\end{tabular}

(Sumber: Analisis data dengan SPSS versi 24, 2020)

Berdasarkan tabel 5.di atas menunjukkan bahwa nilai signifikan (sig) pada Shapiro-Wilkuntuk data hasil Pre-test adalah 0,055 dan Post-test adalah 0,866. Sehingga, karena hasil uji normalitas Pretest dan Post-testlebih besar dari nilai signifikan 0,05 maka data dalam penelitian ini berasal dari populasi yang berdistribusi normal.

2. Uji Hipotesis

Adapun hasil pengujian hipotesis menggunakan uji paired sample t-testpada data pretest dan posttest dapat dilihat pada tabel berikut.

Tabel 6. Hasil uji paired sample t-testpada data Pre-Test dan Post-Test

\begin{tabular}{ll}
\hline Uji t & Sig. (2-tailed) \\
\hline Paired sample t-test & 0,001 \\
\hline
\end{tabular}

(Sumber: Hasil analisis SPSS versi 24, 2020)

Berdasarkan hasil uji paired sample t-testpada tabel diatas diketahui bahwa nilai Sig. (2tailed $=0,001)<1 / 2 \alpha(0,025)$. Sehingga sesuai dengan kaidah pengambilan keputusan jika nilai sig. (2tailed $<1 / 2 \alpha$ makaHO ditolak dan Ha diterima. Dengan demikian dapat diketahui bahwa penggunaan model pembelajaran kooperatif tipeTeam Assisted Individualization(TAI) memiliki pengaruh yang signifikan terhadap kemampuan berpikir kritismatematis siswa kelas VIII SMP Negeri 11 Maros.

\section{Simpulan}

Berdasarkan hasil penelitian dan pembahasan pada bab sebelumnya, maka dapat disimpulkan bahwa penerapan model pembelajaran kooperatif tipe Team Assisted Individualization (TAI) memberikan pengaruh pada kemampuan berpikir kritis matematis siswa berbasis media whatsapp kelas VIII SMP Negeri 11 Maros pada materi bangun ruang sisi datar. Pengaruh tersebut dapat dilihat dari hasil tes kemampuan berpikir kritis matematis siswa yang mengalami perubahan berupa peningkatan dari nilai rata-rata Pre-test $=35,29$ menjadi 60,07 hasil Post-test. Sedangkan berdasarkan pada kategori hasil tes kemampuan berpikir kritismatematis siswa, setelah siswa diberikan perlakuan, persentase kategori hasil tes kemampuan berpikir kritismatematis mengalami perubahan yang baik. Hal ini dapat dilihat dari peningkatan persentase pada kategori sangat baik yaitu dari 7,14\% hasil pretest menjadi $21,43 \%$ hasil Post-test, dan pada kategori sangat kurang persentasenya menurun dari 71,44\% Pre-test menjadi 28,58 \% Post-test. 


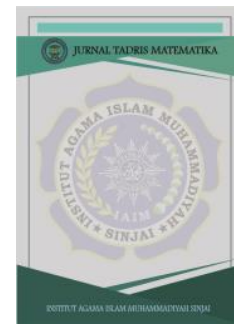

JTMT

Jurnal Tadris Matematika

Vol 1 No 22020

ISSN (print) : 2745-956X

ISSN (online) : 2745-9551

Homepage : http://journal.iaimsinjai.ac.id/index.php/Jtm

Kemudian dari empat indikator kemampuan berpikir kritis matematis setelah diberikan perlakuan berupa proses pembelajaran dengan menggunakan model kooperatif tipe Team Assisted Individualization (TAI) menunjukkan bahwa nilai tertinggi ada pada indikator menganalisis data yaitu sebesar 78,5Post-test dan nilai terendah ada pada indikator kemampuan mengenali adanya hubungan yang logis antar masalah yaitu sebesar 50. Artinya setelah siswa diberikan perlakuan, siswa memiliki kemampuan tertinggi dalam hal menganalisis data. Namun, memiliki kemampuan terendah dalam hal mengenali adanya hubungan yang logis antar masalah.

Adanya pengaruh model pembelajaran kooperatif tipe Team Assisted Individualization (TAI) terhadap kemampuan berpikir kritis siswa berbasis media whatssapp kelas VIII SMP Negeri 11 Maros pada materi bangun ruang sisi datar juga dapat dilihat dari hasil pengujian hipotesis menggunakan uji paired sample t-test dengan nilai Sig. (2-tailed) $<1 / 2 \alpha$ yakni $0,001<0,025$; yang menunjukkan $\mathrm{HO}$ ditolak dan Ha diterima. Sehingga, dengan demikian dapat disimpulkan bahwa terdapat pengaruh signifikan pada siswa yang diajar menggunakan model pembelajaran kooperatif tipe Team Assisted Individualization (TAI) terhadap kemampuan berpikir kritis matematis siswa bebrbasis media whatsapp kelas VIII SMP Negeri 11 Maros pada materi bangun ruang sisi datar.

\section{Daftar Pustaka}

Diana Martiana. (2015). Meningkatkan kemampuan berpikir kritis matematis siswa dengan menggunakan model pembelajaran kooperatif tipe team assisted individualizatian (TAI) [Skripsi tidak dipublikasikan]. universitas islam negeri syarif hidayatullah jakarta.

Ernawati. (2015). Proses Berpikir Siswa Dalam Memecahkan Soal Cerita Matematika Materi Sitem Pertidaksamaan Linear Dua Variabel Ditinjau Dari Gaya Kognitif. 159-368.

Ernawati, E. (2017). Pengaruh Pendekatan Pembelajaran Terhadap Kemampuan Penalaran Dan Komunikasi Matematika Siswa. 3(1), 64-74.

Fitriani. (2020). Kemampuan Pemecahan Masalah Siswa Smp. http://journal.iaimsinjai.ac.id/index.php/Jtm/article/view/393/307

Riyanti, A, Widiyatmoko, A, \& Wusqo, I. U. (2016). Pengaruh Model Pembelajaran Kooperatif Tipe Team Assisted Individualization Berbantuan Peta Konsep Terhadap Hasil Belajar Dan Keterampilan Berpikir Kritis Siswa Smp Tema Kalor.

Setyosari, H. P. (2015). Metode Penelitian Pendidikan dan Pengembangan.

Sumantri, M. S. (2016). Strategi pembelajaran: Teori dan Praktik di tingkat Pendidikan Dasar. Jakarta: Rajawali Pers. 